\title{
A Meta-Analysis of the Event-Related Potential during Auditory Processing in Infants with Familial Risk for Dyslexia and Its Correlation to Language Abilities
}

\author{
Se Jin $\mathrm{Oh}^{\mathrm{a}}$, Dongsun Yim ${ }^{\mathrm{b}}$, Jee Eun Sung \\ ${ }^{a}$ Graduate Program in Communication Disorders, Ewha Womans University, Seoul, Korea \\ ${ }^{b}$ Department of Communication Disorders, Ewha Womans University, Seoul, Korea
}

Correspondence: Dongsun Yim, PhD Department of Communication Disorders, Ewha Womans University, 52 Ewhayeodae-gil, Seodaemun-gu, Seoul 03760, Korea Tel: $+82-2-3277-6720$

Fax: +82-2-3277-2122

E-mail: sunyim@ewha.ac.kr

Received: June 26, 2019

Revised: August 26, 2019

Accepted: August 28, 2019

This work was supported by the Ministry of Education of the Republic of Korea and the National Research Foundation of Korea (NRF-2018S1A3A2075274).

\begin{abstract}
Objectives: Developmental dyslexia is a disorder in which children with normal sensory and cognitive abilities fail to acquire reading and writing skills despite conventional education. Related literature has reported that phonological processing deficits underlie reading and writing difficulties, suggesting that basic auditory processing problems from birth could be the underlying factors of phonological impairment with an emphasis on genetic effects. The current study aimed to investigate whether the event-related potential (ERP) during auditory processing in infants less than 24 months of age with familial risk for dyslexia is significantly different from that of their controls through a meta-analysis, and explore how the ERP correlates to later language abilities. Methods: Database searching identified twelve studies which met the criteria. Effect size (Hedges' $g$ ) was calculated using the Comprehensive Meta-Analysis (CMA). Significant correlation coefficients were reported based on 5 studies analyzing correlation between the ERP and several measurements of later language abilities. Results: The results demonstrated medium to large effect size of the differences in the mean amplitude of ERP, indicating that the ERP is a sensitive measure to distinguish the at-risk group from the control group. The analysis of correlation between the ERP and later language abilities revealed that reading fluency, reading speed, and phonological awareness have relatively strong correlations with the ERP. Conclusion: The current study showed significant differences in the ERP during auditory processing between infants with and without familial risk for dyslexia, suggesting that ERP could be an early electrophysiological marker for developmental dyslexia.
\end{abstract}

Keywords: Developmental dyslexia, Event-related-potential (ERP), Infant auditory processing, Meta-analysis, Language abilities
발달성 난독증(developmental dyslexia)은 정상적 인지능력과 감 각 기제를 가지고 있고, 정상적 교육을 받았음에도 불구하고 읽기 와 쓰기에 어려움을 갖는 학습 장애의 일종이다(Critchley, 1970; Lyon, Shaywitz, \& Shaywitz, 2003). 발달성 난독증의 유병률은 연 구에 따라 차이가 있으나 대략 5\%-17.5\%로 보고되고 있으며(Shaywitz, 1998), 난독증 직계가족이 있는 아동 중 40\%-60\%가 난독증 으로 진단되고(Finucci \& Childs, 1983; Galaburda, LoTurco, Ra- mus, Fitch, \& Rosen, 2006; Vogler, DeFries, \& Decker, 1985), 부모 가 난독증일 경우, 그렇지 않은 경우에 비해 난독증 발생 위험이 8 배 나 높을 정도로 유전성이 높은 장애로 알려져 있다(Lohvansuu, Hämäläinen, Ervast, Lyytinen, \& Leppänen, 2018).

많은 연구들이 난독증과 관련되는 여러 유전자들을 보고해 왔고 (Hulme \& Snowling, 2009; Olson, 2006; Pennington \& Olson, 2005; Williams \& O’Donovan, 2006), 난독증 가족력 연구를 통해 유전 
Se Jin Oh, et al. • Meta-Analysis of ERPs in Infants with Familial Risk for Dyslexia

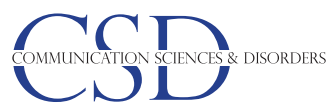

적 영향의 중요성을 입증해왔다(Bishop \& Snowling, 2004; DeFries, Singer, Foch, \& Lewitter, 1978; Muter \& Snowling, 2009; Pennington \& Olson, 2005). 발달성 난독증의 원인을 밝히기 위해 뇌의 구 조적, 기능적 문제점을 찾는 연구들이 진행되고 있으나, 어떤 구조 적, 기능적 특성이 읽기 문제를 유발하는지에 대해서는 아직 명확 하게 밝혀지지 않은 실정이다. 한 가설에 따르면, 대뇌피질발달에 관여하는 유전자들이 비정상적으로 작동하여 신경세포이동(neuronal migration)과 축삭의 성장(axonal growth)에 결함이 생기게 되고, 피질의 구조적 결함 및 피질-피질, 피질-시상 간 회로에 이상을 유발하여, 감각운동(sensorimotor), 지각, 인지 등의 결함이 발생한 다고 알려져 있다(Galaburda et al., 2006). 또한 난독증을 유발하는 유전자는 음운 표상의 저장소로 알려져 있는 두정-측두 영역의 발 달에 관여한다고 보고된 바 있는데(Darki, Peyrard-Janvid, Matsson, Kere, \& Klingberg, 2012; Jahanshad et al., 2012), 관련 유전자 가 손상되면 청각 피질에서 말소리의 신경 표상이 불완전하게 형성 된다는 것이 동물실험과 인간 사후부검연구를 통해 보고되기도 하였다(Centanni et al., 2013). 이러한 연구 결과들은 발달성 난독 증에서 주된 결함으로 보고되고 있는 음운정보 처리 결함에 대한 근거를 제공한다.

난독증의 원인이 음운정보 처리의 결함에 있다는 가설(phonological deficit hypothesis)은 일찍이 많은 학자들에 의해 제안되었 고(Beaton, 2004; Bradley \& Bryant, 1983; Ramus, 2004; Shankweiler \& Liberman, 1972; Snowling, 1981; Stanovich, 1998; Tallal, 1980; Wagner \& Torgesen, 1987), 난독증의 원인에 대한 가설 중에 서 가장 많은 실험적 근거를 가지고 있다(Beaton, 2004). 음운정보 처리는 단어의 의미를 구별해주는 말의 최소 단위인 음소정보를 처 리하는 것을 말한다(Wagner \& Torgesen, 1987). 단어 지식은 어휘 집(mental lexicon) 속에 추상적인 음소열로 저장되어 있는데 (Chomsky \& Halle, 1968), 단어를 적절하게 해독하기 위해서는 단 어가 더 작은 단위인 음소로 구성되어 있음을 이해해야 한다. 난독 아동의 경우, 음소의 인식이나 단어를 음소로 분절하는 능력에 결 함이 있다고 알려져 있으며, 이는 난독증의 주된 원인으로 보고되 어 왔다(Hulme \& Snowling, 2009; Shaywitz, 2003).

음운 처리 결함이 발달성 난독증의 원인이라는 견해는 음운 처 리 결함의 원인을 어디에서 찾느냐에 따라 크게 두 가지 입장으로 나누어진다. 첫 번째 입장은 청각적 정보 처리의 결함이 음운 처리 결함의 원인이라고 보는 입장이다(Farmer \& Klein, 1995; Tallal \& Gaab, 2006). 이 입장을 지지하는 학자들은 청각적 자질(auditory features) 처리의 결함이 불완전한 말소리 표상을 형성하게 하고, 이 것이 음운 처리의 결함으로 이어진다고 주장한다. 또 다른 입장은
난독증의 음운 처리 결함이 어휘단계(lexical level)나 하위 어휘단 계(sublexical level)와 같이 청각적 자질보다 상위 단계에 있는 언어 관련 정보 처리의 결함 때문에 생긴다고 본다(Ramus et al., 2003; White et al., 2006). 이 입장을 지지하는 학자들은 발달성 난독증이 있는 사람들이 청각적 정보 처리에 어려움이 있을 수는 있으나, 청 각적 정보 처리의 결함 자체가 음운정보 처리의 어려움을 유발하 는 것은 아니므로 청각적 정보 처리의 결함이 난독증 발생의 원인 이라고 볼 수는 없다고 주장한다.

청각적 정보 처리 결함이 음운 처리 결함의 원인이라고 주장하 는 학자들이 그 근거로 제안하고 있는 가설 중의 하나는 빠른청각 정보처리결함 가설(rapid auditory processing deficit hypothesis; Farmer \& Klein, 1995; Tallal \& Gaab, 2006)이다. 이 가설에 따르면, 발달성 난독증이 있는 아동은 짧고 빠르게 변화되는 소리를 지각 하는데 결함이 있어서 말소리의 흐름 속에서 빠르게 변화하는 포 먼트 전이(formant transition)를 처리하는 능력이 부족하게 되고, 그 결과 일반 아동에 비해 말소리 지각의 정확도가 감소하게 된다. 이러한 말소리 지각의 결함은 음운 표상(phonological representation)이 불완전하게 형성되는 결과를 초래하며, 불완전한 음운 표 상은 음소 산출의 정확성을 떨어뜨려, 궁극적으로는 읽기나 말하 기 결함을 발생시킨다(Mather \& Wendling, 2012; Shaywitz, 2003). 빠른청각정보처리결함 가설은 난독증 위험인자를 가지고 태어 난 영유아를 대상으로 한 사건관련전위(event-related potential, $\mathrm{ERP})$ 연구를 통해서도 그 타당성이 입증되고 있다. ERP는 비침습 적인 방식의 전기생리학적 기법으로, 영유아를 대상으로 대뇌피질 의 지각 과정을 살펴보는데 있어서 좋은 도구가 될 수 있다(DehaeneLambertz \& Gliga, 2004; Ozernov-Palchik \& Gaab, 2016). 또한 mismatch negativity $(\mathrm{MMN})$ 와 같은 성분을 관찰하는 $\mathrm{ERP}$ 연구 의 경우, 피험자가 잠들어 있는 동안에도 측정이 가능하고 인지나 주의의 영향을 받지 않고서도 측정할 수 있어서, 신생아나 영유아 의 적극적인 협력 없이도 과제 수행의 결과를 얻을 수 있다는 장점 이 있다(Alho, Sainio, Sajaniemi, Reinikainen, \& Näätänen, 1990; Cheour, Korpilahti, Martynova, \& Lang, 2001; Dehaene-Lambertz \& Pena, 2001; Friederici, Friedrich, \& Weber, 2002). ERP 실험에서 는 청각 정보 처리의 결함을 알아보기 위해 주로 오드볼 패러다임 (oddball paradigm)을 사용한다. 오드볼 패러다임은 표준자극 (standard stimulus)과 드문 빈도로 제시되는 변이자극(deviant stimulus)을 처리할 때 나타나는 평균진폭의 차이를 통해 자극에 대한 변별적 처리가 나타나는지를 알아보는 패러다임이다(Squires, Squires, \& Hillyard, 1975). 발달성 난독 아동의 청각적 처리의 특징 을 알아보고자 한 연구들에서는 특정 주파수나 길이 또는 강도를 
변화시킨 소리 자극이나 자음-모음(consonant-vowel, CV), 자음모음-자음(CVC), 모음-자음-모음(VCV)과 같은 음절구조에서 포 먼트 전이 양상을 변화시키거나, 모음 길이를 변화시킨 음절을 자 극으로 사용해 왔다.

이와 같은 실험 패러다임을 사용하여 보고된 난독증 관련 ERP 성분들은 $\mathrm{MMN}$, late discriminative negativity (LDN), N1, P1, P2 등이 있다. $\mathrm{MMN}$ 은 감각기억단계(sensory memory level)에서 발 생하는 부적 방향의 성분으로, 일련의 소리의 흐름 속에서 기본 자 극을 기억함으로써 형성되는 기억 정보에서 변이적 특성을 감지할 때 발생한다(Näätänen, 1995; Näätänen \& Alho, 1997). 이러한 점 에서 $\mathrm{MMN}$ 은 청각 피질에서 일어나는 전주의적인 정보변화감지 (pre-attentive change-detection)의 지표로 알려져 있다(Giard, Perrin, Pernier, \& Bouchet, 1990; Näätänen, 1995; Näätänen \& Alho, 1997). 또한 MMN은 음운인식 및 읽기 발달과 직접적으로 연관되어 있어 발달적인 측면에서도 매우 중요한 ERP 성분으로 보 고된 바 있다(Elbro, Borstrøm, \& Petersen, 1998). MMN은 대게 정 점을 이루는 것으로 관찰되지 않으며 지연 시간에 있어서도 편차가 커서, 효과 파악을 위해서는 평균진폭이 많이 사용된다(Lee, Sung, Lee, Moon, \& Kim, 2014; McGee, Kraus, \& Nicol, 1997). 또한 아동 을 대상으로 한 연구에서는 변이자극 처리 시 나타나는 성분이 정 적 성분인 경우도 보고되고 있어서(Pihko et al., 1999; Van Leeuwen et al., 2006, 2008), MMR (mismatch response)이라는 용어를 사용 하기도 한다(van Zuijen et al., 2012). $\mathrm{LDN}$ 은 MMN과 유사한 패러 다임에서 관찰되는 성분으로 $400 \mathrm{~ms}$ 무렵에 발생하는 뇌파이다. 그 기능에 대해서는 명확하게 알려져 있지 않으나, 표준자극과 변이자 극의 차이를 처리하는 것과 관련이 있다고 보고된 바 있다(Cheour et al., 2001). N1은 자극 제시 후 $100 \mathrm{~ms}$ 정도에서 부적 정점으로 나 타나는 성분으로 청각적 환경에서 소리의 시작과 같은 일시적인 변 화를 감지하는 인지적 활동을 반영하며, 전두-중앙(fronto-central) 영역에서 가장 큰 진폭을 보인다고 알려져 있다(Näätänen \& Picton, 1987). P1, P2의 경우 자극인식(stimulus awareness) 또는 자극변이 (variation) 인식의 지표로 보고된 바 있으며(Čeponienè, Alku, Westerfield, Torki, \& Townsend, 2005; Luck, 2014), 진폭의 저하는 자극 차이 인식의 결함을 반영한다. 난독증 위험군 영유아를 대상으로 한 선행연구들에서는 이러한 성분들이 난독증 위험 집단과 통제 집 단을 구분하는 지표가 될 수 있음을 보고해 왔다(Bonte, Poelmans, \& Blomert, 2007; Liu, Chen, \& Tsao, 2014; Sharma et al., 2006; Stanovich, 1988). 난독증 위험군 영유아의 경우 변이자극에 대한 진폭 이 감소하거나, 표준자극과 변이자극의 차이가 나타나지 않는 등, 통제군과는 다른 ERP 특징이 나타난다는 결과들이 보고되었고,
이는 음운정보 처리의 결함의 근거로 제시되어 왔다.

난독증으로 진단된 아동 및 위험군 아동을 대상으로 $\mathrm{MMN}$ 성분 을 관찰한 연구들로 메타분석을 실시한 Volkmer와 Schulte-Koerne (2018)의 연구에서는 총 7편의 논문으로 효과크기를 산출하여 ERP 측정치가 난독증 위험군과 통제 집단을 구분하는 정도가 연령에 따라 다르게 나타났음을 보고하였다. 주로 발달초기 위험군 영유 아에서는 $\mathrm{MMN}$ 성분의 평균진폭이 통제군에 비해 유의하게 감소 되어 나타났지만, 3.5 세에서 7세 사이의 아동에서는 진폭이 감소되 기도 하고 증가되기도 하는 등 그 결과가 이질적임을 보고하였다. 연령이 증가할수록 ERP 패턴이 이질적으로 나타난다는 것은 감각 적인 정보 처리 발달에 있어서의 개인차가 연령이 증가할수록 커진 다는 것을 의미하며, 개인의 인지 및 언어발달이 청각적 정보나음운 정보 처리 능력에 영향을 미칠 수 있음을 시사한다. 또한 부모로부 터 물려받은 난독증과 관련된 유전적인 영향이 발달상의 여러 요인 들에 의해서 약화될 수 있음을 시사한다. 그러나 Volkmer와 SchulteKoerne (2018)에서는 다양한 연령대에서 얻은 논문들을 연령대 구 분 없이 한꺼번에 분석에 투입하여 하나의 효과크기를 산출했다는 제한점이 있다. 효과크기 산출을 위해 투입된 7편의 논문들을 종 합해 보았을 때, 대상 아동의 범위는 0 세에서 7 세로 그 범위가 매우 넓었다. 해당 연구에서도 밝혔듯이, 난독증 위험군 아동의 발달 초 기에 관찰되는 ERP에 비해 언어발달이 진행되면서 나타나는 ERP 의 개인차는 커진다. 이는 난독증 조기진단 측정치로서의 ERP의 효과크기가 연령대별로 달라질 수 있음을 시사한다. 따라서 ERP가 난독증 조기진단 도구로서 가치가 있는지를 알아보기 위해서는 연 령대별로 구분하여 효과크기를 분석해볼 필요가 있다. Volkmer와 Schulte-Koerne (2018)의 또 다른 제한점으로는 메타분석에 포함된 대상자가 난독증 가족력이 있는 영유아뿐만 아니라, 이후의 읽기 또는 쓰기능력이 저하되어 있지만 가족력은 없는 아동들의 ERP 결 과도 포함하여 효과크기를 산출했다는 점이다. 난독증 가족력이 없는 아동을 분석에 포함하였으므로, 난독증 가족력이 청각적 정 보 처리에 미치는 영향을 추론하는 데는 제한이 있을 수 있다. 또한 본 연구에서 분석하고자 하는 발달 초기 영유아를 대상으로 한 연 구들은 분석된 7 편의 연구 중 2 편에 불과하여, 보고된 결과만으로 는 ERP가 난독증 위험군 집단과 통제 집단을 구분하는 유의한 측 정치인지를 종합적으로 판단하기 어렵다는 제한점이 있다. 따라서 본 연구에서는 난독증 조기진단 도구로서의 $\mathrm{ERP}$ 의 유용성을 알아 보기 위해 난독증 가족력이 있는 24 개월 미만의 영유아로 분석대 상을 좁혀, 초기 ERP가 난독증 위험군 집단과 통제 집단을 구분하 는 전기생리학적인 지표가 될 수 있는지를 알아보고자 하였다.

발달 초기의 $\mathrm{ERP}$ 와 이후의 언어능력의 상관에 대한 연구는 제 
한적이다. 학령전기에 측정된 음운인식능력, 빠른이름대기(rapid automatized naming, RAN), 철자지식, 구어 단기기억 등과 학령기 의 읽기능력은 밀접한 상관이 있다는 결과들이 보고된 바 있으나 (Vellutino, Fletcher, Snowling, \& Scanlon, 2004), 발달 초기의 청각 적 처리능력과 읽기 또는 쓰기능력의 상관에 대해서는 거의 알려져 있지 않은 실정이다(Lohvansuu et al., 2018). 난독증 가족력이 있는 영유아를 대상으로 한 연구들에서 난독증 위험군의 음운 처리 결 함이 보고된 바 있으므로(Mather \& Wendling, 2012; Shaywitz, 2003), 난독증 위험군 영유아에게서 관찰되는 ERP 또한 이후의 언 어능력과 밀접한 연관이 있을 가능성이 있다. 발달 초기 ERP와 이 후의 언어능력과의 상관을 다룬 논문은 그 수가 매우 제한적이며, 이를 종합적으로 보고한 논문 또한 아직 보고되지 않았다. 따라서 본 연구에서는 ERP와 이후의 언어능력과의 상관을 보고한 논문의 결과를 종합하여 상관의 경향성을 알아보고자 한다.

난독증의 진단은 대부분 읽기 학습을 시작하는 학령기가 되어 서야 이루어진다. 중재 시기가 늦어질수록 일반아동과의 격차가 더 욱 벌어져 이를 만회하기 위해 더 많은 노력이 필요하며, 읽기 관련 경험도 줄어들 수밖에 없다(Torgesen, 2002). 난독증의 조기 중재 의 중요성이 여러 연구들을 통해 입증되었다는 것을 고려하면 (Torgesen, 2002; Wanzek \& Vaughn, 2007), 난독증의 진단 시기를 앞당겨 발달 초기에 집중적인 중재를 위한 노력을 기울여야 한다. 난독증 조기진단 및 중재를 위한 노력의 일환으로, 난독증 가족력 이 있는 영유아의 정보 처리상의 차이를 반영하는 전기생리학적인 지표를 발견하게 된다면, 난독증 발생에 있어서의 유전적 영향을 줄이고, 정상적인 읽기 발달이 이루어지도록 하는데 도움을 줄 수 있을 것이다.

따라서 본 연구는 ERP가 난독증 가족력이 있는 난독증 위험군 영유아와 통제 집단을 구분하는 유의한 측정치인지를 메타분석을 통해 알아보고자 하였다. 나아가 발달 초기 청각적 자극 처리 시 측 정된 ERP가 이후의 언어능력과 어떠한 상관이 있는지를 상관 결 과를 제시한 논문들에 근거하여 분석하고자 하였다.

\section{연구방법}

\section{문헌 검색}

난독증 가족력이 있는 영유아의 청각적 정보 처리에서 나타나는 $\mathrm{ERP}$ 의 특징을 분석하기 위해 2018년 11월 29일에 국내외 데이터베 이스와 관련 논문의 참고문헌 검색을 통해 논문을 수집하였다. 국 외 데이터베이스로 PsycINFO, PubMed, Web of Science, Academic Search Complete, CINAHL Plus, ERIC을, 국내 데이터베이스로
RISS, DBpia, Kyobo Scholar를 선정하였다. 본 연구의 목적은 난독 증 진단에 대한 전기생리학적인 지표로서의 $\mathrm{ERP}$ 의 유용성을 파악 하는데 있으므로 ERP 성분의 유형에는 특별한 제한을 두지 않았 다. 현재까지 출간된 모든 논문들을 대상으로 검색어(Dyslexi $\mathrm{OR}$ "reading disorder" OR "reading disabilit*" OR "reading difficut*) AND ("MMR" OR "Mismatch Response" OR "MMN" OR "Mismatch Negativity" OR oddball OR "event related potential*”) AND (risk OR "famil ${ }^{\star}$ risk" OR "famil ${ }^{\star}$ dyslexia”) AND (“infant" OR “newborn”)를 사용하여 검색을 실시하였다.

\section{논문의 선정 기준}

검색을 실시한 결과, PsycINFO에서 20편, PubMed에서 16편, Web of Science에서 15편, Academic Search Complete에서 6편, CINAHL Plus에서 6편, ERIC에서 2편, RISS, DBpia, Kyobo Schol$\operatorname{ar}$ 에서 0 편으로 총 65 편의 논문이 검색되었다. 검색된 논문에서 전 문 이용가능 여부, peer reviewed journal의 논문, 영어로 작성된 논 문을 선정 기준으로 하여 총 64 편의 논문을 선정하였으며, 중복된 논문을 제외한 21 편의 논문을 선정하였다. 이 논문들 중에서 (1) 신 생아부터 24 개월까지의 난독증 가족력을 가진 영유아를 대상으로 한 논문, (2) 측정 기법으로 ERP를 사용한 논문, (3) 집단 비교 연구, (4) 측정치로 ERP 평균진폭을 보고한 논문을 포함 기준으로 하여 총 12 편의 논문을 분석 대상으로 선정하였다. 논문 선정 과정을 도 식화한 순서도와 논문 선정에 사용된 포함 및 제외 기준은 각각 Figure 1과 Table 1에 제시하였다.

\section{자료의 분석}

자료의 코딩 및 분석

선정된 논문들의 특징을 파악하기 위해 연구자, 출판년도, 실험 집단 및 통제 집단에 대한 기본 정보, 표본수, 과제 유형, 전극 위치, $\mathrm{ERP}$ 성분에 대한 정보를 정리하여 Table 2에 제시하였다. 효과크 기 산출을 위해서는, 각 연구에서 집단 간 ERP 평균진폭 차이의 유 의성을 검증하기 위해 사용한 $F$ 값과 $t$ 값을 사용하였고, 표본크기 가 작은 연구에서 효과크기가 과대 추정되는 문제점을 고려하여, 교정된 표준화된 평균차이인 Hedges' $g$ 를 산출하였다. 또한 본 연 구의 목적이 난독증 위험군과 통제군을 구분하는 측정치로서 ERP 의 유용성을 고찰해보는데 있었고, 연구마다 분석 구간 및 전극 채 널의 위치가 다르고, 집단 간 차이가 유의한 구간들이 다양하게 나 타나는 점을 고려하여, 집단 차이에 대해 산출된 통계치 중 가장 큰 값을 사용하여 효과크기를 산출하였다. 효과크기의 유의성은 유 의수준 .05 및 $95 \%$ 신뢰구간을 기준으로 검증하였고, 포함된 연구 


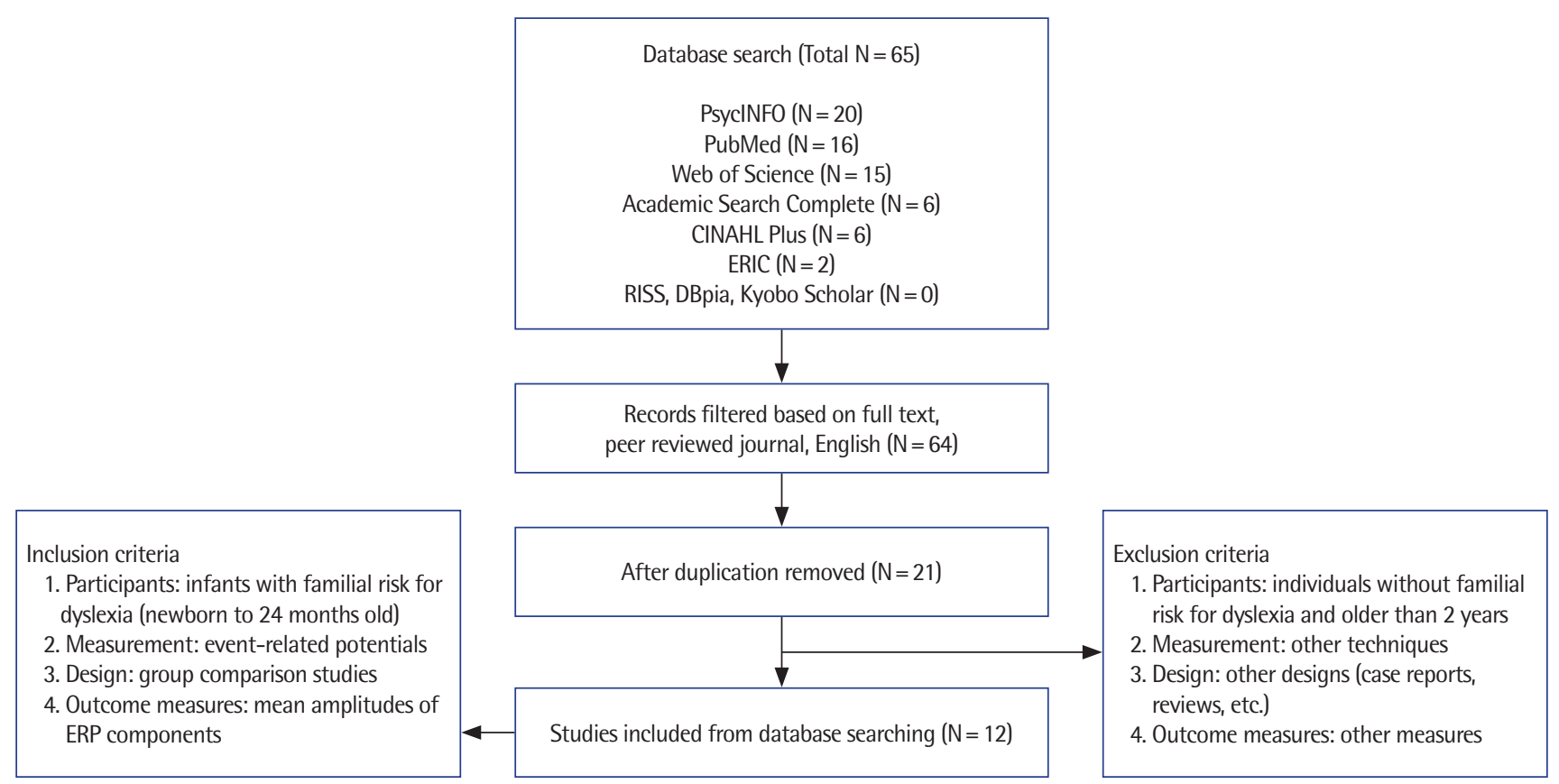

Figure 1. Flowchart showing literature search.

Table 1. Inclusion and exclusion criteria for studies

\begin{tabular}{lll}
\hline \multicolumn{2}{c}{ Inclusion } & \multicolumn{1}{c}{ Exclusion } \\
\hline Participants & Infants with familial risk for dyslexia (newborn to 24 months old) & Individuals without familial risk for dyslexia and older than 2 years \\
Measurement & Event-related potentials & Other techniques \\
Design & Group comparison design & Other designs (case reports, reviews, etc.) \\
Outcome measures & Mean amplitudes of ERP components & Other measures \\
\hline
\end{tabular}

$E R P=$ event-related potential.

들의 이질성을 고려하여 무선효과모형을 이용한 분석을 실시하였 다. 메타분석을 위한 소프트웨어는 Comprehensive Meta-Analysis (CMA 2.0)를 사용하였다. 영유아기 때 측정한 ERP의 평균진폭과 이후 연령대에서 나타난 읽기 및 쓰기능력과의 상관 분석에 대해서 는, 분석에 포함된 12 편의 논문 중에서 상관 결과를 제시한 3 편의 결과와 분석에 포함된 논문의 ERP 결과를 이용하여 상관 분석만 실시한 2편의 논문을 추가하여 총 5편의 결과를 기술하였다. 발달 초기의 ERP 평균진폭과 이후의 언어능력과의 상관 분석 결과를 제시함에 있어, 읽기 또는 쓰기 관련 변수에 국한시키지 않고, 읽기 능력에 영향을 미칠 수 있을 것이라 판단되는 다른 언어적 변수도 포함하여 결과를 제시하였다. 각 연구에서 보고된 효과크기 및 상 관의 정도는 Cohen (1988)을 기준으로 해석하였다.

\section{출판편향 검증}

본 연구에 포함된 연구들이 출판편향을 가지는지를 funnel plot
을 이용하여 확인한 결과, 추정된 평균 효과크기를 기준으로 비대 칭을 이루어 출판편향의 가능성을 확인하였다(Figure 2). 통계적 검증을 위해, Egger의 회귀분석(Egger, Smith, Schneider, \& Minder, $1997)$ 을 실시한 결과, 절편은 bias $=2.79(t(10)=8.51, p<.01)$ 로 나 타나 출판편향이 존재하는 것으로 나타났다. 출판편향을 보정하기 위해, 결측 연구들의 영향을 보정하는 방법인 trim-and-fill 방법 (Duval, 2005)을 사용하였다. 결측된 연구의 수는 5개로 추정되었 으며, 이 연구들을 반영하여 출판편향이 없는 상태에서 산출된 효 과크기는 .715에서 .617로 감소되었으나, 여전히 통계적으로 유의하 였다(95\% 신뢰구간[.473, .760]; Figure 3). 또한 검정통계량이 유의 하지 않도록 하기 위해 필요한 결측 연구의 수를 나타내는 fail-safe $\mathrm{N}$ 을 구한 결과 249편으로, Rosenthal (1979)이 제시한 기준인 5k (연구수) +10 인 70 편보다 크므로 산출된 전체 효과크기가 출판편 향에 의해 받는 영향은 크지 않음을 확인하였다. 


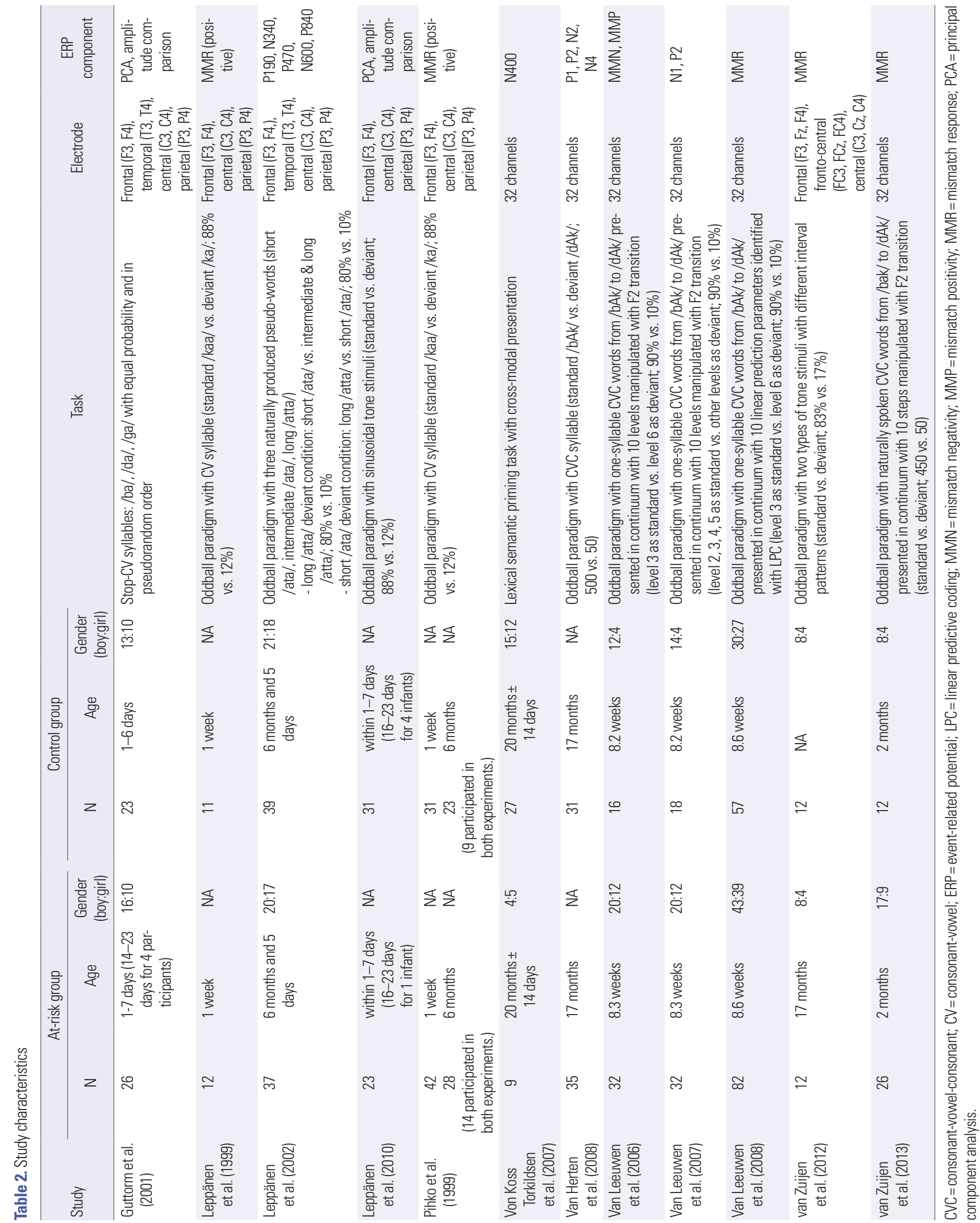




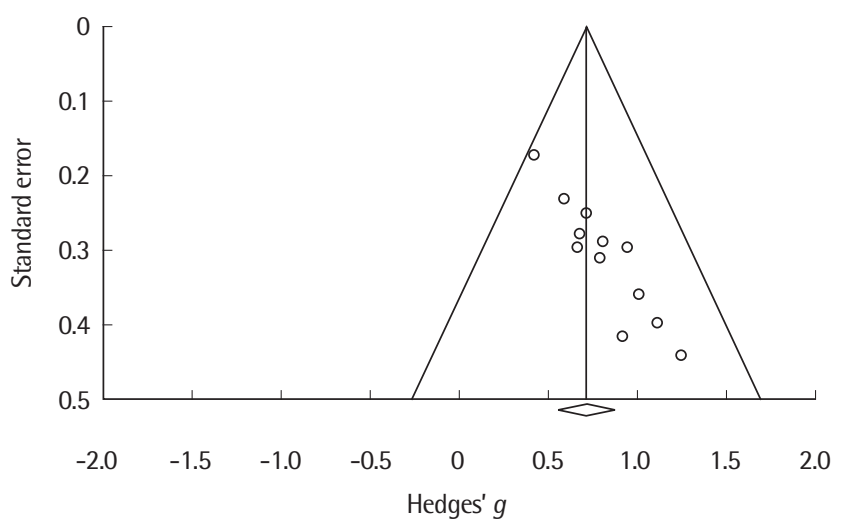

Figure 2. Funnel plot of standard error by Hedges' $g$.

\section{연구결과}

\section{연구의 특징분석}

본 연구에 포함된 12 개 논문의 특징은 Table 2에 제시하였다. 대 상자들은 모두 24 개월 미만의 영유아들로, 난독증 가족력을 가진 위험군 382 명, 통제군 322 명, 총 704 명의 대상자가 분석에 포함되었 다. 난독증 위험군으로 포함된 대상자들은 모두 부모 중 적어도 한 사람 또는 가까운 친척 중에 난독증으로 진단된 자가 있는 영유아 들이었다. 실험에서 사용된 자극 및 패러다임은 연구에 따라 차이 가 있었는데, 음절자극으로 오드볼 패러다임(oddball paradigm)을 사용한 연구가 8 편으로 대부분을 차지하였고, 신호음자극으로 오 드볼 패러다임을 사용한 연구가 2 편, 음절자극을 동일한 비율로 제 시한 연구가 1 편, 단어자극으로 점화 과제 패러다임을 사용한 연구 가 1 편이었다. 실험에 사용된 전극에 대해서는 전두엽, 두정엽, 측두 엽에 위치한 일부 전극을 사용한 연구들이 6편, 32채널을 사용한 연구가 6편이었다.

\section{메타분석 결과}

난독증 위험군 영유아 집단과 통제 집단 간 $\mathrm{ERP}$ 평균진폭 차이 에 대한 표준화된 평균차이를 분석한 결과, 통합된 효과크기는 $g=.715, p<.001,95 \%$ 신뢰구간[.556, .875]으로 중간에서 큰 효과 크기의 값을 보이는 것으로 나타났으며(Cohen, 1988), 이러한 결과 는 통계적으로 유의하였다. 연구별 효과크기를 살펴보면, 대략 8 이상의 큰 효과크기를 보인 연구가 총 12 편 중에 7 편, .4 이상의 중 간 효과크기를 보인 연구가 5편으로 나타났으며, 분석된 모든 개별 연구의 효과크기 또한 통계적으로 유의한 것으로 나타났다. 메타 분석 결과는 Table 3 와 Figure 4 에 제시하였다.

분석에 포함된 개별 연구들의 효과크기의 동질성 여부를 알아

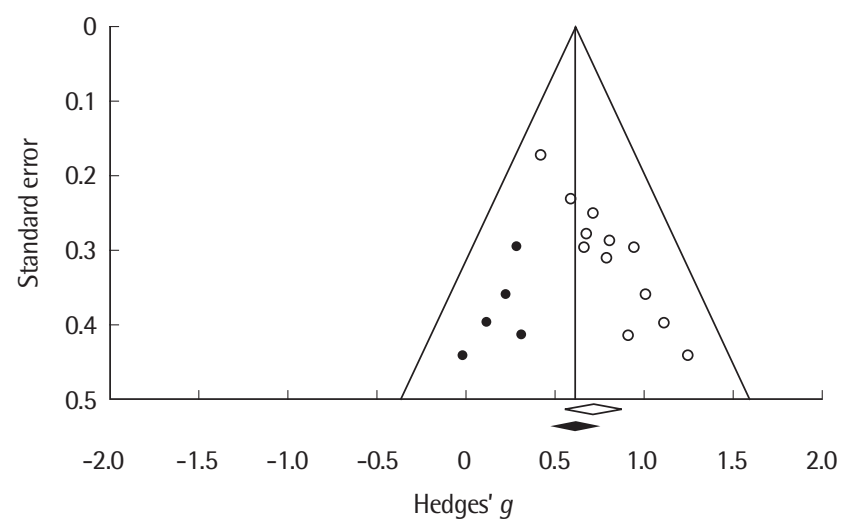

Figure 3. Imputed funnel plot of standard error by Hedges' $g$.

Table 3. Overall effect size of outcome measures between at-risk and control groups

\begin{tabular}{lcccc}
\hline \multirow{2}{*}{$\begin{array}{l}\text { Effect size } \\
\text { (Hedges' g) }\end{array}$} & Standard error & \multicolumn{2}{c}{ 95\% confidence interval } & \\
\cline { 3 - 4 } & & Lower & Upper & \\
\hline .715 & .082 & .556 & .875 & .000 \\
\hline
\end{tabular}

보기 위해 동질성 검증 통계값인 Cochran's $Q$ 를 산출한 결과, 연구 들 간 효과크기에 유의한 차이가 없는 것으로 나타났다 $(Q=7.282$, $d f=11, p>.05)$. 또한 연구 간 이질성 정도를 나타내는 Higgins' $I^{2}$ 를 산출한 결과, $I^{2}=.000$ 으로 연구 간 이질성은 매우 낮은 것으로 나타 났다(Higgins, Thompson, Deeks, \& Altman, 2003).

\section{$\mathrm{ERP}$ 와 이후 언어능력 간 상관}

난독증 가족력이 있는 영유아를 대상으로 24개월 미만 시기에 측정한 $\mathrm{ERP}$ 와 이후의 언어능력과의 상관을 다룬 연구는 12 편의 논문 중 3편(Leppänen et al., 2010; Van Zuijen et al., 2012; Van Zuijen, Plakas, Maassen, Maurits, \& Van der Leij, 2013)이었다. 또한 분석에 포함된 논문들의 ERP 결과로 이후의 언어능력과의 상관을 별도로 분석한 논문은 2편(Guttorm et al., 2005; Lohvansuu et al., 2018)이었다. 이 5편의 논문에서 제시한 초기 ERP와 연령에 따른 여러 하위 언어능력 간 상관 분석 결과는 다음과 같다.

생후 1-7일 신생아를 대상으로 $\mathrm{ERP}$ 를 측정하여 3.5세, 5세, 9세 때의 다양한 읽기 및 쓰기능력과의 상관을 분석한 Leppänen 등 (2010) 연구에서는 주성분 분석(principal component analysis, $\mathrm{PCA}$ )을 통해 시간대별로 분석된 ERP 주요한 성분들이 3.5세 때의 음운인식, 5 세 때의 구어 단기기억(verbal short term memory), 빠 른이름대기(rapid automatized naming), 표현어휘, 철자지식, 9세 때의 음운지속시간인식(phoneme duration perception), 읽기속도, 
Study name

$\begin{array}{lccccccc} & \begin{array}{c}\text { Hedges's } \\ \text { g }\end{array} & \begin{array}{c}\text { Standard } \\ \text { error }\end{array} & \text { Variance } & \begin{array}{c}\text { Lower } \\ \text { limit }\end{array} & \begin{array}{c}\text { Upper } \\ \text { limit }\end{array} & \text { Z-Value } & \text { p-Value } \\ \text { Guttorm et al. (2001) } & 0.946 & 0.297 & 0.088 & 0.363 & 1.528 & 3.179 & 0.001 \\ \text { Leppanen et al. (1999) } & 1.249 & 0.442 & 0.196 & 0.382 & 2116 & 2.823 & 0.005 \\ \text { Leppanen et al. (2002) } & 0.591 & 0.232 & 0.054 & 0.136 & 1.046 & 2.545 & 0.011 \\ \text { Leppanen et al. (2010) } & 0.678 & 0.279 & 0.078 & 0.131 & 1.225 & 2.431 & 0.015 \\ \text { Pihko et al. (1999) } & 0.809 & 0.288 & 0.083 & 0.244 & 1.375 & 2.806 & 0.005 \\ \text { Torkildsen et al. (2007) } & 1.113 & 0.399 & 0.159 & 0.332 & 1.894 & 2.792 & 0.005 \\ \text { van Herten et al. (2008) } & 0.715 & 0.252 & 0.063 & 0.222 & 1.208 & 2.842 & 0.004 \\ \text { van Lœumen et al. (2006) } & 0.790 & 0.312 & 0.097 & 0.179 & 1.401 & 2.533 & 0.011 \\ \text { van Leumen et al. (2007) } & 0.663 & 0.297 & 0.088 & 0.080 & 1.246 & 2.228 & 0.026 \\ \text { van Lœumen et al. (2008) } & 0.423 & 0.173 & 0.030 & 0.083 & 0.763 & 2.439 & 0.015 \\ \text { van Zuijen et al. (2012) } & 0.916 & 0.416 & 0.173 & 0.101 & 1.731 & 2.203 & 0.028 \\ \text { van Zuijen et al. (2013) } & 1.007 & 0.361 & 0.130 & 0.300 & 1.714 & 2.793 & 0.005 \\ & 0.715 & 0.082 & 0.007 & 0.556 & 0.875 & 8.770 & 0.000\end{array}$

Hedges's $\mathrm{g}$ and $95 \% \mathrm{Cl}$

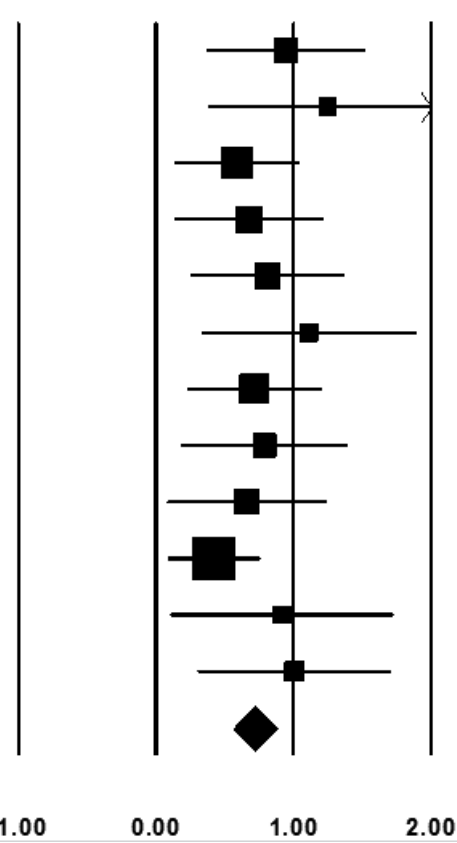

Figure 4. Forest plot of effect sizes of group differences in the mean amplitude of event-related potentials (ERPs).

읽기 및 쓰기정확도와 어떠한 상관이 있는지를 살펴보았다. 주성분 으로 분석된 ERP 성분들은 이후의 모든 언어능력 측정치와 유의한 상관이 있었다. 상관이 비교적 높게 나타난 주성분들의 통계치를 기준으로 상관의 정도를 제시하면, 3.5 세 때의 음운인식과의 상관 은 중도에서 강한 정적 상관 $(r=.403, p<.01)$ 을 보이는 것으로 나타 났으며, 5 세 때의 표현어휘 $(r=.382, p<.01)$, 구어 단기기억 $(r=.337$, $p<.05)$, 빠른이름대기 $(r=.311, p<.05)$, 철자지식 $(r=.304, p<.05)$ 과는 중도의 정적 상관을 보이는 것으로 나타났다. 9 세 때의 읽기속 도 $(r=.458, p<.01)$ 및 음운지속시간인식 $(r=.410, p<.01)$ 과는 모 두 중도에서 강한 정적 상관을 보이는 것으로 나타났으며, 읽기정 확도 $(r=.335, p<.05)$ 및 쓰기정확도 $(r=.353, p<.05)$ 와는 중도의 정적 상관을 보이는 것으로 나타났다.

17 개월 때 측정한 $\mathrm{ERP}$ 와 이후의 언어능력과의 상관을 측정한 Van Zuijen 등(2012)의 연구에서는 53개월 때의 언어이해, 표현통 사(expressive syntax), 표현어휘, 구어 단기기억, 7 세 전반의 음운인 식, 빠른숫자이름대기(RAN digit), 철자지식, 7세 후반의 단어 및 유사단어 읽기유창성(정해진 시간 내에 정확하게 읽은 단어수)과 의 상관을 분석하였다. 분석 결과, ERP 평균진폭은 53 개월 때의 언 어이해 $(r=.422, p<.05)$ 와 유의한 중도에서 강한 정적 상관이 있었 고, 7 세 후반의 일음절단어 읽기유창성 $(r=.416, p<.05)$ 과 자음군
포함단어 읽기유창성 $(r=.461, p<.05)$ 과는 중도에서 강한 정적 상 관이, 다음절단어 읽기유창성 $(r=.502, p<.05)$ 및 유사단어 읽기유 창성 $(r=.523, p<.05)$ 과는 강한 정적 상관이 있는 것으로 나타났 다. 반면 Van Zuijen 등(2013)의 연구에서는 2개월 때의 ERP와 4세 때의 언어이해력과 7세 때의 단어 및 유사단어 읽기유창성과의 상 관을 분석하였는데, 어떤 측정치와도 유의한 상관이 나타나지 않 았다.

효과크기 분석에 포함된 논문들의 ERP 결과로 이후의 언어능력 과의 상관을 별도로 분석한 논문들 중 하나인 Lohvansuu 등(2018) 은 Leppänen 등(2002)에서 측정한 생후 6개월의 난독증 위험군 영 유아의 ERP 평균진폭과 5.5세 때의 음운인식, 빠른이름대기, 구어 단기기억, 철자이름대기, 8 세 때의 비구어 지능, 읽기정확도, 읽기속 도, 10 세와 14 세 때의 읽기정확도와 속도와의 상관을 분석하였다. 분석 결과, $\mathrm{ERP}$ 의 부적 진폭은 5.5 세 때의 음운인식 $(r=-.66, p<$ $.001)$ 및 빠른이름대기 $(r=.64, p<.001)$ 와 14 세 때의 읽기속도 $(r=$ $-.66, p<.001)$ 와 강한 상관이 있는 것으로 나타났다. 또한 Guttorm 등(2005)의 연구에서는 Guttorm, Leppänen, Richardson과 Lyytinen (2001)의 연구에서 제시한 생후 1-6일 이내에 측정된 ERP 결과 와 2.5세, 3.5 세, 5 세 때의 언어능력과의 상관을 분석하였다. 본 논 문에서는 좌, 우뇌에서 측정된 평균진폭 각각에 대해 상관 분석을 
실시하였는데, 투입된 모든 ERP 평균진폭값이 부적 방향으로 커질 수록 수용 및 표현언어 점수가 증가하는 경향을 보였다. 좌뇌에서 측정된 $\mathrm{ERP}$ 부적진폭과 5 세 때의 구어 기억 $(r=-.474, p<.003)$, 우 뇌의 부적진폭과 2.5 세 때의 수용언어 $(r=-.426, p<.01)$ 및 5 세 때 의 수용언어 $(r=-.395, p<.01)$ 와는 중도에서 강한 상관이 있는 것 으로 나타났다. 또한 좌뇌의 ERP 부적진폭과 2.5 세 때의 수용언어 $(r=-.289, p<.05), 3.5$ 세 때의 수용 $(r=-.291, p<.05)$ 및 표현언어 $(r=-.314, p<.05)$, 구어 기억 $(r=-.321, p<.05), 5$ 세 때의 수용 $(r=$ $-.374, p<.01)$ 및 표현언어 $(r=-.272, p<.05)$ 와는 중도의 상관이 있 는 것으로, 우뇌에서 측정된 $\mathrm{ERP}$ 부적진폭과 5 세 때의 표현언어 $(r=-.267, p<.05)$ 및 구어 기억 $(r=-.308, p<.05)$ 과도 중도의 상관 이 있는 것으로 나타났다.

\section{논의 및 결론}

본 연구는 난독증 가족력이 있는 난독증 위험군 영유아를 대상 으로 청각적 정보 처리 시 나타난 ERP가 난독증 위험군과 통제군 을 구분하는 민감한 전기생리학적인 지표가 될 수 있는지를 메타 분석을 통해 알아보았다. 또한 영유아 시기에 측정된 ERP 평균진 폭이 이후의 언어능력과 어떤 상관이 있는지를 살펴보았다.

발달 초기의 ERP가 난독증 위험군과 통제군을 구분할 수 있는 측정치가 될 수 있는지를 알아보기 위해 난독증 가족력이 있는 24 개월 미만의 영유아를 대상으로 한 12 편의 논문을 분석하였다. 통 합된 효과크기는 중간에서 큰 효과크기 $(g=.715)$ 를 가지는 것으로 나타났으며, 포함된 연구 12 편 중 7 편이 대략 .8 이상의 비교적 큰 효과크기를 가지는 것으로 나타났다. 포함된 개별 연구들 간 효과 크기의 이질성 또한 매우 낮은 것으로 나타나, ERP 평균진폭은 난 독증 위험군과 통제군을 비교적 안정적으로 구분하는 측정치인 것 으로 나타났다. 이러한 결과는 난독증 위험군 아동은 출생 직후부 터 청각적 신호 또는 음운정보의 처리에서 난독증 가족력이 없는 아동과 차이가 있다는 것을 시사한다.

난독증 가족력이 있는 영유아에게서 나타난 발달 초기 ERP 평 균진폭의 차이는 청각적 정보의 차이를 변별하여 처리하는 능력이 일반아동에 비해 저하되어 있음을 보여주는 결과이다. 난독증 위 험군 영유아에서 청각적 자극에 대한 변별력이 손상되어 있다는 것은, 입력된 청각적 자극에 대한 음운 표상이 불완전하게 형성될 가능성을 시사하며, 이러한 불완전한 음운 표상으로 인해 음운처 리능력에서의 결함이 나타날 수 있음을 시사한다. 분석에 포함된 많은 연구들은 표준자극 대비 변이자극 처리의 특징을 분석할 수 있는 오드볼 패러다임을 사용하였는데, 난독증 위험군 영유아의
경우, 변이자극에 대해 나타나는 MMR 성분이 나타나지 않거나 통 제 집단과는 다른 변이된 형태로 나타난다는 결과를 보고하였다 (Leppänen et al., 2002; Van Herten et al., 2008; Van Leeuwen et al., 2006, 2007, 2008; Van Zuijen et al., 2012).

난독증 위험군 영유아에게서 $\mathrm{MMR}$ 성분이 정상적으로 나타나 지 않는 현상에 대해서는 여러 견해가 제시되고 있다. 오드볼 과제 에서 변이된 자극에 대해 구별된 반응을 보이기 위해서는 표준자 극에 대한 기억흔적(memory trace)이 적절하게 형성되어야 하고, 이에 근거하여 변이자극에 대한 감지가 이루어져야 한다(Winkler \& Czigler, 1998). 그러나 난독증 위험군 아동은 청각적 신호에 대한 표상을 형성하는데 효율성이 저하되어 있어, 표준자극에 대한 표 상이 불완전하게 형성되어 변이자극에 대한 구별된 반응이 나타나 지 않는다는 것이다(Leppänen et al., 2002). 청각적 자극에 대한 기 억흔적이 적절하게 형성되지 않은 증거는 난독증 위험군 영유아에 게서 나타난 N4 진폭의 특징에서도 나타난다(Van Herten et al., 2008). N4 진폭은 자극이 반복적으로 제시될 때 나타나는 성분으 로, 반복된 진폭에 대한 효율적인 처리의 결과로 진폭이 감소하는 경향이 있다. 그런데 난독증 위험군 영유아에게서는 이러한 진폭 의 저하가 나타나지 않았고, 통제 집단에 비해 평균진폭의 크기가 크게 나타나는 경향이 있었다. 이는 표준자극에 대한 기억이 불완 전하게 형성되어 표준자극을 효율적으로 처리하는 능력이 부족하 여 나타난 현상일 수 있다. 난독 아동의 음운 표상 형성의 효율성 저하가 난독증의 원인이 된다는 주장은 일찍부터 제기되어 왔다 (Kuhl, 1991). 청각적 자극에 대해 기억을 형성하는 능력은 장기기 억 속에 저장되는 말소리 표상의 형성에도 기초가 될 수 있다(Leppänen et al., 2002). 청각적 정보에 대한 기억이 불완전하게 저장되 면 음운 표상 또한 불완전하게 저장되며, 범주적 지각능력의 결함 (Steffens, Eilers, Gross-Glenn, \& Jallad, 1992; Werker \& Tees, 1987)이나 음운 정보 처리의 어려움이 야기될 수 있다(Leppänen et al., 2002; McBride-Chang, 1995). 말소리 표상이 불완전하게 형성 되는 현상은 학습장애 아동(Kraus et al., 1996) 및 난독증 성인(Kujala et al., 2000)의 ERP 실험을 통해서도 보고된 바 있다. 또한 이러 한 말소리 표상의 결함으로 인해 음운처리능력이 손상된다는 것이 말소리장애 아동의 행동실험 결과(Bae, Ha, Koo, Hwang, \& Pyun, 2016)나, 뇌손상환자 연구(Cho \& Pyun, 2015; Cho, Jung, \& Nam, 2002)를 통해서도 보고되었다.

난독증 위험군 영유아에게서 변이자극에 대한 구별된 반응이 나 타나지 않은 또 다른 이유로 언급될 수 있는 것은 위험군 집단이 변 이자극의차이를 인식하지 못했을 가능성이다. Van Herten 등(2008) 의 연구에서는 난독증 위험군의 경우 통제 집단에 비해 $\mathrm{P} 1, \mathrm{P} 2$ 의 
진폭이 유의하게 감소된 현상을 보고하였고, Van Leeuwen 등(2007) 의 연구에서는 N1 진폭의 유의한 저하를 보고하였다. 이러한 진폭 의 저하는 일시적으로 변하는 변이자극 처리의 결함을 보여주는 근거가 될 수 있다. 즉, 난독증 위험군 아동은 변이자극의 상이한 특징을 충분히 강하게 인식하지 못하기 때문에 변이자극 처리로 인해 나타나는 ERP 성분이 나타나지 않을 수 있다는 것이다. 자음 지각의 경우, 자음과 모음 사이에서 빠르게 변화하는 포먼트 전이 를 제대로 인식할 수 있어야 개별 음소지각이 제대로 이루어진다 (Fucci \& Lass, 1999). 이처럼 빠르게 변화하는 포먼트 전이를 적절 하게 처리하지 못하면, 자음지각의 정확도가 떨어질 수 있다.

음운자극을 사용한 이러한 실험결과는 언어적 신호자극뿐만 아 니라 비언어적 신호자극 처리 시에도 동일하게 나타났다(Leppänen et al., 2010; Van Zuijen et al., 2012). 이는 난독증의 원인으로 여겨 지는 청각적 정보 처리의 결함이 반드시 언어적인 부분에 국한되지 않는다는 것을 시사하며, 청각적 정보 처리 가설을 지지하는 결과 이기도 하다. 그러나 본 메타분석에 포함된 연구 중 비언어적인 소 리자극을 사용한 연구는 두 편에 불과하므로 난독증 위험군 아동 의 비언어적 자극 처리에 대한 일반화된 해석을 하는 데는 주의가 필요하다.

종합해 보면, 본 연구결과는 난독증 위험군 영유아의 발달 초기 에 나타나는 청각적 정보 처리의 결함은 발달성 난독증이 기본적인 청각적 자질 처리의 결함에서 비롯된다는 가설(Farmer \& Klein, 1995; Tallal \& Gaab, 2006)을 지지하는 근거가 될 수 있다. 또한 이 러한 결과는 난독 아동에게서 나타나는 음운처리능력의 결함이 불완전한 음운 표상의 형성에서 비롯될 수 있음을 시사한다.

난독증 가족력이 있는 영유아의 ERP 특징을 통해 밝혀진 또 하 나의 흥미로운 사실은 대뇌반구 편재화에 대한 내용이다. 말소리 처리에는 좌뇌가 우세하게 개입한다는 것이 일반적으로 받아들여 지고 있는데(Carr \& Posner, 1995; Neville, Kutas, \& Schmidt, 1982), 난독증 위험군 영유아의 경우, 변이자극에 대한 반응이 우반구에 서 나타나기도 하고, 변이자극에 대한 좌반구의 반응이 감소하거 나 정점이 지연되는 현상을 보였다(Brunswick \& Rippon, 1994; Guttorm et al., 2001; Leppänen, Pihko, Eklund, \& Lyytinen, 1999; Molfese, 2000; Van Herten et al., 2008; Van Leeuwen et al., 2007). 이러한 결과는 난독 아동의 말소리 처리 시 청각적 및 언어적 정보 처리를 담당하는 뇌의 영역이 다르게 개입될 가능성 및 좌뇌 중심 의 언어 처리와는 다른 반구 특성화를 보여주는 결과이다. 난독증 위험군 아동 또는 난독증으로 진단된 대상자의 우반구 활성화의 증가는 어려운 과제 수행 시에 나타나는 보상적인 처리일 수도 있고 (Guttorm et al., 2001), 좌반구 언어처리 영역의 불완전한 기능을 보
충하기 위한 보상 기재일 수도 있다(Coltheart, 2000). 좌반구 언어 처리의 불완전함은 좌뇌의 구조적 발달의 결함을 보고한 연구에 의해서도 뒷받침 된다. Démonet, Taylor, \& Chaix (2004) 연구는 발 달성 난독증이 있는 사람들에게서 나타나는 좌뇌의 구조적 변형 (malformation)에 대해 보고하면서 발달성 난독증이 뇌 성숙의 결 함 때문에 생긴 현상이라고 주장하기도 하였다. 즉, 정상적인 뇌 성 숙의 과정에서는 언어기능에 대해서는 좌뇌 우세현상이 뚜렷해 지 는데, 난독 아동은 좌뇌의 성숙이 지연되어, 좌뇌 기능이 부적절한 상태로 남아 있게 된다는 것이다(Satz, Rardin, \& Ross, 1971).

본 연구에서는 난독증 가족력이 있는 영유아의 ERP 특징이 이후 의 언어능력과 어느 정도 관련이 있는지를 알아보기 위해 ERP 평균 진폭과 이후의 언어능력과의 상관을 분석하였다. 분석된 논문의 수 가 제한되어 있고, 언어능력 변수의 유형 및 측정 시기, 투입된 ERP 평균진폭의 시간대와 위치 또한 다양하여 종합적인 결론을 내리는 데 주의를 기울여야 하지만, 그 경향성을 살펴보면 다음과 같다.

발달 초기에 측정된 $\mathrm{ERP}$ 와 이후의 언어능력 간 상관의 정도는 언어능력의 유형에 따라 다르게 나타났다. 읽기유창성이나 읽기속 도, 음운인식능력은 다른 변수들에 비해 비교적 강한 상관을 보였 다. 읽기정확도나 읽기속도 및 읽기유창성과 같은 읽기 관련 변수 와 ERP의 상관은 4 편의 연구에서 분석되었는데, 한 편을 제외하고 는 모두 유의한 중도에서 강한 상관을 보이는 것으로 나타났다. 이 러한 결과는 영유아 및 학령전기 아동의 ERP 반응이 이후의 읽기 능력 분산의 많은 부분을 설명한다고 보고한 선행연구(Leppänen et al., 2010; Van Zuijen et al., 2012, 2013)의 결과와도 일치한다. 전 반적인 경향성을 통해 볼 때, 발달 초기 ERP는 이후 읽기발달을 보 여주는 초기 측정치로서의 가치가 있음을 시사한다고 볼 수 있다. 언어이해와의 상관에 관해서는 2.5 세에서 5 세 때의 언어이해 점수 와 ERP 진폭과의 상관을 분석한 연구들이 있었는데, 3 편 중 2 편의 연구에서 중도의 유의한 상관을 보였고, 언어표현과의 상관 또한 3 편의 연구에서 분석되었는데, 제시된 상관의 정도는 약한에서 중 도의 상관을 보이는 것으로 나타났다. 음운인식, 구어 단기기억, 빠 른이름대기, 쓰기정확도, 철자지식과 같은 항목과는 중도에서 강한 상관을 보이는 결과들이 제시되었으나, 분석된 논문이 한 두 편에 불과해 종합된 결론을 도출하기에는 어려웠다. 그러나 본 분석결과 는 발달 초기의 청각적 정보 처리 능력이 이후의 읽기능력이나 언어 이해 및 표현능력과 관련이 있을 수 있으며, 발달 초기의 ERP가 이 후의 언어능력을 예측하는 도구로 사용될 수 있을 가능성을 제안 한다고 볼 수 있다.

한 가지 분명히 고려해야 할 점은 영유아 시기에 측정된 ERP가 절대적 기준은 될 수 없으며, 가족력이 있는 모든 아동이 난독증을 
갖게 되는 것은 아니라는 점이다. 난독 아동의 일부만이 청각적 처 리 능력에 결함이 있다는 것은 선행연구를 통해서 보고된 바 있으 며(Ramus et al., 2003), 난독증의 발현은 유전적 요인, 개인의 인지 능력 및 이후의 언어적 경험과 같은 환경적인 요인 모두의 영향을 받는다고 볼 수 있다. 예컨대 난독증 가족력이 있다 하더라도 읽기 에서 유창한 아동은 전반적으로 지능이 높았다는 결과가 ERP 연 구와 난독 아동을 대상으로 한 행동 연구에서 보고된 바 있다(Van Bergen, De Jong, Plakas, Maassen, \& Van der Leij, 2012). 또한 난 독증 가족력이 있는 아동의 발달 초기 ERP가 이후의 읽기능력 정 도를 예측할 수 있는지를 알아본 연구들도 이러한 사실을 뒷받침 해주는데, 난독증 위험군 영유아의 경우, 이후의 읽기 수준과 관계 없이, 발달 초기의 ERP 진폭이 통제 집단에 비해작거나(Leppänen et al., 2010; Plakas, Van Zuijen, Van Leeuwen, Thomson, \& Van der Leij, 2013), ERP 패턴과 분포에 있어서 차이가 있음을 보고하였 다(Van Zuijen et al., 2013). 이는 청각적 정보 처리에 있어서 유전적 인 영향을 $\mathrm{ERP}$ 를 통해 뚜렷하게 보여준 증거라고도 할 수 있지만 한편으로는 출생 초기의 청각적 정보 처리의 차이가 반드시 난독 증으로 이어지지는 않는다는 것을 시사하기도 한다.

본 연구의 제한점은 다음과 같다. 분석에 포함된 연구들은 가족 력이 있는 영유아 난독증 위험군을 대상으로 실시한 ERP 연구로 대부분 네덜란드와 핀란드에서 시행된 난독증 대규모 프로젝트로 부터 보고된 연구들이다. 따라서 각 연구마다 연구에 참여한 대상 과 실험방법은 다르지만, 언어적, 문화적 다양성이 부족할 수 있다. 또한 ERP 특징과 이후의 언어능력과의 상관을 분석한 부분은 연 구수의 제한으로 일반화된 결론을 도출하는데 제한점이 있었다. 제시된 결과에 대해서는 해석상의 주의가 필요할 것으로 생각되며, 발달 초기에 측정된 ERP가 이후의 언어능력을 예측하는지를 알아 보기 위해서는 발달 초기에 나타난 ERP와 이후의 발달 단계별로 나타나는 여러 하위 언어능력과의 상관을 살펴보는 종단연구가 이 루어져야할 것이다.

난독증의 조기진단과 중재는 난독증 치료에 매우 중요하다는 사 실이 널리 받아 들여짐에도 불구하고(Torgesen, 2000; Wanzek \& Vaughn, 2007), 난독증 진단은 보통 읽기교육이 이루어지는 시기 가 되어서야 이루어진다(Ozernov-Palchik \& Gaab, 2016; Pihko et al., 1999). 난독증의 조기진단 및 중재를 위해서는 난독증 위험군 아동의 발달 초기부터 나타나는 특성을 분석하는 다양한 기초연 구 및 이를 종합적으로 분석한 연구들이 필요하리라 생각된다. 본 연구는 발달 초기에 청각적 정보 처리 시 나타나는 ERP가 난독증 가족력이 있는 영유아와 통제 집단을 구별할 수 있는 민감한 측정 치임을 보여주었으며, 발달성 난독증의 조기진단을 위한 유용한 기
법으로 ERP가 사용될 수 있을 가능성을 시사한다.

\section{REFERENCES}

Alho, K., Sainio, K., Sajaniemi, N., Reinikainen, K., \& Näätänen, R. (1990). Event-related brain potential of human newborns to pitch change of an acoustic stimulus. Electroencephalography and Clinical Neurophysiology/ Evoked Potentials Section, 77(2), 151-155.

Bae, S. R., Ha, J. W., Koo, M. M., Hwang, Y. M., \& Pyun, S. B. (2016). New phonological representation of children with speech sound disorders. Communication Sciences \& Disorders, 21(1), 24-36.

Beaton, A. (2004). Dyslexia, reading and the brain: a sourcebook of psychological and biological research. New York, NY: Psychology Press.

Bishop, D. V., \& Snowling, M. J. (2004). Developmental dyslexia and specific language impairment: same or different? Psychological Bulletin, 130(6), 858-886.

Bonte, M. L., Poelmans, H., \& Blomert, L. (2007). Deviant neurophysiological responses to phonological regularities in speech in dyslexic children. Neuropsychologia, 45(7), 1427-1437.

Bradley, L., \& Bryant, P. E. (1983). Categorizing sounds and learning to read: a causal connection. Nature, 301(5899), 419-421.

Brunswick, N., \& Rippon, G. (1994). Auditory event-related potentials, dichotic listening performance and handedness as indices of lateralisation in dyslexic and normal readers. International Journal of Psychophysiology, 18(3), 265-275.

Carr, T. H., \& Posner, M. I. (1995). The impact of learning to read on the functional anatomy of language processing. In B. de Gelder and J. Morais (Eds.), Language and literacy: comparative approaches (pp. 267-294). London: Routledge.

Centanni, T. M., Booker, A. B., Sloan, A. M., Chen, F., Maher, B. J., Carraway, R. S., ... \& Kilgard, M. P. (2013). Knockdown of the dyslexia-associated gene KIAA0319 impairs temporal responses to speech stimuli in rat primary auditory cortex. Cerebral Cortex, 24(7), 1753-1766.

Čeponienė, R., Alku, P., Westerfield, M., Torki, M., \& Townsend, J. (2005). ERPs differentiate syllable and nonphonetic sound processing in children and adults. Psychophysiology, 42(4), 391-406.

Cheour, M., Korpilahti, P., Martynova, O., \& Lang, A. H. (2001). Mismatch negativity and late discriminative negativity in investigating speech perception and learning in children and infants. Audiology and Neurotology, $6(1), 2-11$. 
Cho, H., \& Pyun, S. B. (2015). Characteristics of acquired phonological dyslexia in Korean. Communication Sciences \& Disorders, 20(4), 570-586.

Cho, K., Jung, J., \& Nam, K. (2002). Lexical processing in acquired Hangul dyslexia. Korean Journal of Communication \& Disorders, 7(3), 1-20.

Chomsky, N., \& Halle, M. (1968). The sound pattern of English. New York, NY: Harper \& Row.

Cohen, J. (1988). Statistical power analysis for the behavioral sciences. Hillsdale, NJ: Lawrence Erlbaum Associates.

Coltheart, M. (2000). Deep dyslexia is right-hemisphere reading. Brain and Language, 71(2), 299-309.

Critchley, M. (1970). The dyslexic child. London: Heinemann Medical.

Darki, F., Peyrard-Janvid, M., Matsson, H., Kere, J., \& Klingberg, T. (2012). Three dyslexia susceptibility genes, DYX1C1, DCDC2, and KIAA0319, affect temporo-parietal white matter structure. Biological Psychiatry, 72(8), 671-676.

DeFries, J. C., Singer, S. M., Foch, T. T., \& Lewitter, F. I. (1978). Familial nature of reading disability. The British Journal of Psychiatry, 132(4), 361-367.

Dehaene-Lambertz, G., \& Gliga, T. (2004). Common neural basis for phoneme processing in infants and adults. Journal of Cognitive Neuroscience, 16(8), 1375-1387.

Dehaene-Lambertz, G., \& Pena, M. (2001). Electrophysiological evidence for automatic phonetic processing in neonates. Neuroreport, 12(14), 3155-3158.

Démonet, J. F., Taylor, M. J., \& Chaix, Y. (2004). Developmental dyslexia. The Lancet, 363(9419), 1451-1460.

Duval, S. (2005). The trim and fill method. In H. R. Rothstein et al. (Eds.), Publication bias in meta-analysis: prevention, assessment and adjustments (pp. 127-144). Hoboken, NJ: John Wiley \& Sons.

Egger, M., Smith, G. D., Schneider, M., \& Minder, C. (1997). Bias in meta-analysis detected by a simple, graphical test. BMJ, 315(7109), 629-634.

Elbro, C., Borstrøm, I., \& Petersen, D. K. (1998). Predicting dyslexia from kindergarten: the importance of distinctness of phonological representations of lexical items. Reading Research Quarterly, 33(1), 36-60.

Farmer, M. E., \& Klein, R. M. (1995). The evidence for a temporal processing deficit linked to dyslexia: a review. Psychonomic Bulletin \& Review, 2(4), 460-493.

Finucci, J. M., \& Childs, B. (1983). Dyslexia: family studies. In C. L. Ludlow and J. A. Cooper (Eds.), Genetic aspects of speech and language disorders (pp. 157-167). New York, NY: Academic Press.

Friederici, A. D., Friedrich, M., \& Weber, C. (2002). Neural manifestation of cognitive and precognitive mismatch detection in early infancy. Neurore- port, 13(10), 1251-1254.

Fucci, D. J., \& Lass, N. J. (1999). Fundamentals of speech science. Boston, MA: Allyn \& Bacon.

Galaburda, A. M., LoTurco, J., Ramus, F., Fitch, R. H., \& Rosen, G. D. (2006). From genes to behavior in developmental dyslexia. Nature Neuroscience, 9(10), 1213-1217.

Giard, M. H., Perrin, F., Pernier, J., \& Bouchet, P. (1990). Brain generators implicated in the processing of auditory stimulus deviance: a topographic event-related potential study. Psychophysiology, 27(6), 627-640.

Guttorm, T. K., Leppänen, P. H., Poikkeus, A. M., Eklund, K. M., Lyytinen, P., \& Lyytinen, H. (2005). Brain event-related potentials (ERPs) measured at birth predict later language development in children with and without familial risk for dyslexia. Cortex, 41(3), 291-303.

Guttorm, T. K., Leppänen, P. H., Richardson, U., \& Lyytinen, H. (2001). Eventrelated potentials and consonant differentiation in newborns with familial risk for dyslexia. Journal of Learning Disabilities, 34(6), 534-544.

Higgins, J. P., Thompson, S. G., Deeks, J. J., \& Altman, D. G. (2003). Measuring inconsistency in meta-analyses. BMJ, 327(7414), 557-560.

Hulme, C., \& Snowling, M. J. (2009). Developmental disorders of language learning and cognition. Hoboken, NJ: John Wiley \& Sons.

Jahanshad, N., Kohannim, O., Hibar, D. P., Stein, J. L., McMahon, K. L., de Zubicaray, G. I., ... \& Wright, M. J. (2012). Brain structure in healthy adults is related to serum transferrin and the $\mathrm{H} 63 \mathrm{D}$ polymorphism in the HFE gene. Proceedings of the National Academy of Sciences, 109(14), E851-E859.

Kraus, N., McGee, T. J., Carrell, T. D., Zecker, S. G., Nicol, T. G., \& Koch, D. B. (1996). Auditory neurophysiologic responses and discrimination deficits in children with learning problems. Science, 273(5277), 971-973.

Kuhl, P. K. (1991). Perception, cognition, and the ontogenetic and phylogenetic emergence of human speech. In S. E. Brauth et al. (Eds.), Plasticity of development (pp. 73-106). Cambridge, MA: MIT Press.

Kujala, T., Myllyviita, K., Tervaniemi, M., Alho, K., Kallio, J., \& Näätänen, R. (2000). Basic auditory dysfunction in dyslexia as demonstrated by brain activity measurements. Psychophysiology, 37(2), 262-266.

Lee, S. H., Sung, K., Lee, K. S., Moon, E., \& Kim, C. G. (2014). Mismatch negativity is a stronger indicator of functional outcomes than neurocognition or theory of mind in patients with schizophrenia. Progress in NeuroPsychopharmacology and Biological Psychiatry, 48, 213-219.

Leppänen, P. H., Hämäläinen, J. A., Salminen, H. K., Eklund, K. M., Guttorm, T. K., Lohvansuu, K., ... \& Lyytinen, H. (2010). Newborn brain event-related potentials revealing atypical processing of sound frequency and the subse- 
quent association with later literacy skills in children with familial dyslexia. Cortex, 46(10), 1362-1376.

Leppänen, P. H., Pihko, E., Eklund, K. M., \& Lyytinen, H. (1999). Cortical responses of infants with and without a genetic risk for dyslexia. II. Group effects. Neuroreport, 10(5), 969-973.

Leppänen, P. H., Richardson, U., Pihko, E., Eklund, K. M., Guttorm, T. K., Aro, M., \& Lyytinen, H. (2002). Brain responses to changes in speech sound durations differ between infants with and without familial risk for dyslexia. Developmental Neuropsychology, 22(1), 407-422.

Liu, H. M., Chen, Y., \& Tsao, F. M. (2014). Developmental changes in mismatch responses to Mandarin consonants and lexical tones from early to middle childhood. PLoS One, 9(4), e95587.

Lohvansuu, K., Hämäläinen, J. A., Ervast, L., Lyytinen, H., \& Leppänen, P. H. (2018). Longitudinal interactions between brain and cognitive measures on reading development from 6 months to 14 years. Neuropsychologia, 108, 6-12.

Luck, S. J. (2014). An introduction to the event-related potential technique. Cambridge, MA: MIT Press.

Lyon, G. R., Shaywitz, S. E., \& Shaywitz, B. A. (2003). A definition of dyslexia. Annals of Dyslexia, 53(1), 1-14.

Mather, N., \& Wendling, B. J. (2012). Essentials of dyslexia assessment and intervention. Hoboken, NJ: John Wiley \& Sons.

McBride-Chang, C. (1995). Phonological processing, speech perception, and reading disability: an integrative review. Educational Psychologist, 30(3), 109-121.

McGee, T., Kraus, N., \& Nicol, T. (1997). Is it really a mismatch negativity? An assessment of methods for determining response validity in individual subjects. Electroencephalography and Clinical Neurophysiology/Evoked Potentials Section, 104(4), 359-368.

Molfese, D. L. (2000). Predicting dyslexia at 8 years of age using neonatal brain responses. Brain and Language, 72(3), 238-245.

Muter, V., \& Snowling, M. J. (2009). Children at familial risk of dyslexia: practical implications from an at-risk study. Child and Adolescent Mental Health, 14(1), 37-41.

Näätänen, R. (1995). The mismatch negativity: a powerful tool for cognitive neuroscience. Ear and Hearing, 16(1), 6-18.

Näätänen, R., \& Alho, K. (1997). Mismatch negativity: the measure for central sound representation accuracy. Audiology and Neurotology, 2(5), 341-353.

Näätänen, R., \& Picton, T. (1987). The N1 wave of the human electric and magnetic response to sound: a review and an analysis of the component structure. Psychophysiology, 24(4), 375-425.

Neville, H. J., Kutas, M., \& Schmidt, A. (1982). Event-related potential studies of cerebral specialization during reading. I. Studies of normal adults. Brain and Language, 16(2), 300-315.

Olson, R. K. (2006). Genetic and environmental influences on the development of reading and related cognitive skills. In R. Malatesha Joshi and P. G. Aaron (Eds.), Handbook of orthography and literacy (pp. 707-722). Mahwah, NJ: Lawrence Erlbaum Associates.

Ozernov-Palchik, O., \& Gaab, N. (2016). Tackling the 'dyslexia paradox': reading brain and behavior for early markers of developmental dyslexia. Wiley Interdisciplinary Reviews: Cognitive Science, 7(2), 156-176.

Pennington, B. F., \& Olson, R. K. (2005). Genetics of dyslexia. In M. J. Snowling \& C. Hulme (Eds.), The science of reading: a handbook (pp. 453-472). Malden, MA: Blackwell.

Pihko, E., Leppänen, P. H., Eklund, K. M., Cheour, M., Guttorm, T. K., \& Lyytinen, H. (1999). Cortical responses of infants with and without a genetic risk for dyslexia. I. Age effects. Neuroreport, 10(5), 901-905.

Plakas, A., van Zuijen, T., van Leeuwen, T., Thomson, J. M., \& van der Leij, A. (2013). Impaired non-speech auditory processing at a pre-reading age is a risk-factor for dyslexia but not a predictor: an ERP study. Cortex, 49(4), 1034-1045.

Ramus, F. (2004). Neurobiology of dyslexia: a reinterpretation of the data. Trends in Neurosciences, 27(12), 720-726.

Ramus, F., Rosen, S., Dakin, S. C., Day, B. L., Castellote, J. M., White, S., \& Frith, U. (2003). Theories of developmental dyslexia: insights from a multiple case study of dyslexic adults. Brain, 126(4), 841-865.

Rosenthal, R. (1979). The file drawer problem and tolerance for null results. Psychological Bulletin, 86(3), 638-641.

Satz, P., Rardin, D., \& Ross, J. (1971). An evaluation of a theory of specific developmental dyslexia. Child Development, 42(6), 2009-2021.

Shankweiler, D., \& Liberman, I. Y. (1972). Misreading: a search for causes. In J. F. Kavanagh \& I. G. Mattingly (Eds.), Language by ear and by eye: the relationships between speech and reading (pp. 293-317). Cambridge, MA: MIT Press.

Sharma, M., Purdy, S. C., Newall, P., Wheldall, K., Beaman, R., \& Dillon, H. (2006). Electrophysiological and behavioral evidence of auditory processing deficits in children with reading disorder. Clinical Neurophysiology, 117(5), 1130-1144.

Shaywitz, S. E. (1998). Dyslexia. New England Journal of Medicine, 338(5), 307-312. 
Se Jin Oh, et al. • Meta-Analysis of ERPs in Infants with Familial Risk for Dyslexia

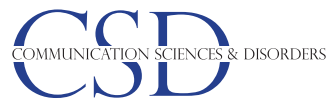

Shaywitz, S. E. (2003). Overcoming dyslexia: a new and complete science-based program for reading problems at any level. New York, NY: Knopf.

Snowling, M. J. (1981). Phonemic deficits in developmental dyslexia. Psychological Research, 43(2), 219-234.

Squires, N. K., Squires, K. C., \& Hillyard, S. A. (1975). Two varieties of longlatency positive waves evoked by unpredictable auditory stimuli in man. Electroencephalography and Clinical Neurophysiology, 38(4), 387-401.

Stanovich, K. E. (1988). Explaining the differences between the dyslexic and the garden-variety poor reader: the phonological-core variable-difference model. Journal of Learning Disabilities, 21(10), 590-604.

Stanovich, K. E. (1998). Refining the phonological core deficit model. Child Psychology and Psychiatry Review, 3(1), 17-21.

Steffens, M. L., Eilers, R. E., Gross-Glenn, K., \& Jallad, B. (1992). Speech perception in adult subjects with familial dyslexia. Journal of Speech, Language, and Hearing Research, 35(1), 192-200.

Tallal, P. (1980). Auditory temporal perception, phonics, and reading disabilities in children. Brain and Language, 9(2), 182-198.

Tallal, P., \& Gaab, N. (2006). Dynamic auditory processing, musical experience and language development. Trends in Neurosciences, 29(7), 382-390.

Torgesen, J. K. (2000). Individual differences in response to early interventions in reading: the lingering problem of treatment resisters. Learning Disabilities Research \& Practice, 15(1), 55-64.

Torgesen, J. K. (2002). The prevention of reading difficulties. Journal of School Psychology, 40(1), 7-26.

Van Bergen, E., De Jong, P. F., Plakas, A., Maassen, B., \& van der Leij, A. (2012). Child and parental literacy levels within families with a history of dyslexia. Journal of Child Psychology and Psychiatry, 53(1), 28-36.

Van Herten, M., Pasman, J., van Leeuwen, T. H., Been, P. H., van der Leij, A., Zwarts, F., \& Maassen, B. (2008). Differences in AERP responses and atypical hemispheric specialization in 17-month-old children at risk of dyslexia. Brain Research, 1201, 100-105.

Van Leeuwen, T., Been, P., Kuijpers, C., Zwarts, F., Maassen, B., \& van der Leij, A. (2006). Mismatch response is absent in 2-month-old infants at risk for dyslexia. Neuroreport, 17(4), 351-355.

Van Leeuwen, T., Been, P., van Herten, M., Zwarts, F., Maassen, B., \& van der Leij, A. (2007). Cortical categorization failure in 2-month-old infants at risk for dyslexia. Neuroreport, 18(9), 857-861.

Van Leeuwen, T., Been, P., van Herten, M., Zwarts, F., Maassen, B., \& van der
Leij, A. (2008). Two-month-old infants at risk for dyslexia do not discriminate/bAk/from/dAk: a brain-mapping study. Journal of Neurolinguistics, 21(4), 333-348.

Van Zuijen, T. L., Plakas, A., Maassen, B. A., Been, P., Maurits, N. M., Krikhaar, E., ... \& van der Leij, A. (2012). Temporal auditory processing at 17 months of age is associated with preliterate language comprehension and later word reading fluency: an ERP study. Neuroscience Letters, 528(1), 31-35.

Van Zuijen, T. L., Plakas, A., Maassen, B. A., Maurits, N. M., \& van der Leij, A. (2013). Infant ERPs separate children at risk of dyslexia who become good readers from those who become poor readers. Developmental Science, 16(4), 554-563.

Vellutino, F. R., Fletcher, J. M., Snowling, M. J., \& Scanlon, D. M. (2004). Specific reading disability (dyslexia): what have we learned in the past four decades? Journal of Child Psychology and Psychiatry, 45(1), 2-40.

Vogler, G. P., DeFries, J. C., \& Decker, S. N. (1985). Family history as an indicator of risk for reading disability. Journal of Learning Disabilities, 18(7), 419-421.

Volkmer, S., \& Schulte-Koerne, G. (2018). Cortical responses to tone and phoneme mismatch as a predictor of dyslexia? A systematic review. Schizophrenia Research, 191, 148-160.

Von Koss Torkildsen, J., Syversen, G., Simonsen, H. G., Moen, I., \& Lindgren, M. (2007). Brain responses to lexical-semantic priming in children at-risk for dyslexia. Brain and Language, 102(3), 243-261.

Wagner, R. K., \& Torgesen, J. K. (1987). The nature of phonological processing and its causal role in the acquisition of reading skills. Psychological Bulletin, 101(2), 192-212.

Wanzek, J., \& Vaughn, S. (2007). Research-based implications from extensive early reading interventions. School Psychology Review, 36(4), 541-561.

Werker, J. F., \& Tees, R. C. (1987). Speech perception in severely disabled and average reading children. Canadian Journal of Psychology, 41(1), 48-61.

White, S., Milne, E., Rosen, S., Hansen, P., Swettenham, J., Frith, U., \& Ramus, F. (2006). The role of sensorimotor impairments in dyslexia: a multiple case study of dyslexic children. Developmental Science, 9(3), 237-255.

Williams, J., \& O’Donovan, M. C. (2006). The genetics of developmental dyslexia. European Journal of Human Genetics, 14(6), 681-689.

Winkler, I., \& Czigler, I. (1998). Mismatch negativity: deviance detection or the maintenance of the 'standard'. NeuroReport, 9(17), 3809-3813. 


\section{국문초록}

\section{난독증 가족력이 있는 영유아의 청각적 정보 처리 시 나타난 사건관련전위에 대한 메타분석 및 이후 언어능력과의 상관 연구 \\ 오세진 ${ }^{1}$ 임동선 ${ }^{2} \cdot$ 성지은 ${ }^{2}$}

${ }^{1}$ 이화여자대학교 대학원 언어병리학과, ${ }^{2}$ 이화여자대학교 언어병리학과

배경 및 목적: 본 연구는 난독증 가족력이 있는 발달성 난독증 위험군 영유아의 청각적 정보 처리 시 나타난사건관련전위(event-related potential, ERP)를 보고한 연구들을 종합적으로 분석하여 ERP가 난독증 위험군 집단을 민감하게 구분하는지를 알아보고, 발달 초기 의 ERP가 이후의 언어능력과 어떠한 상관이 있는지를 알아보고자 하였다. 방법: 국내외 9 개 데이터베이스에서 24 개월 미만의 난독증 가족력이 있는 영유아의 ERP 평균진폭을 비교한 12편의 논문을 선정하여 교정된 표준화된 평균차이인 Hedges' $g$ 를 산출하였다. 또한 발달 초기의 $\mathrm{ERP}$ 와 이후의 언어능력 측정치 간 상관을 분석한 5 편의 논문에 근거하여 상관 정도를 분석하였다. 결과: 난독증 위험군 집단과 통제 집단 간 ERP 평균진폭에 대한 효과크기는 중간에서 큰 효과크기를 보이며 발달 초기의 ERP가 난독증 위험군과 통제군을 구분하는 유의한 측정치인 것으로 나타났다. 또한 $\mathrm{ERP}$ 와 이후의 언어능력 간 상관의 정도는 언어능력의 유형에 따라 다르게 나타났으 며, 읽기유창성이나 읽기속도, 음운인식능력에서 비교적 강한 상관을 보이는 것으로 나타났다. 논의 및 결론: 본 연구는 발달 초기에 청 각적 정보 처리 시 나타나는 ERP가 난독증 가족력이 있는 영유아와 통제 집단을 구별할 수 있는 민감한 측정치임을 보여주었으며, 발달 성 난독증의 조기진단을 위한 유용한 기법으로 ERP가 사용될 수 있을 가능성을 시사한다.

핵심어: 발달성 난독증, ERP, 영유아 청각적 정보 처리, 메타분석, 언어능력

본 논문은 2019년 대한민국 교육부와 한국연구재단의 지원을 받아수행된 연구임(NRF-2018S1A3A2075274).

\section{참고문헌}

배세령, 하지완, 구민모, 황유미, 편성범(2016). 말소리장애아동의 새로운 음운표상 형성 능력. Communication Sciences \& Disorders, 21(1), 24-36. 조경덕, 정재범, 남기춘(2002). 후천성 한글 난독증의 어휘처리 양상. 언어청각장애연구, 7(3), 1-20.

조혜숙, 편성범(2015). 한국어 후천성 음운성 실독증의 특성. Communication Sciences \& Disorders, 20(4), 576-580.

\section{ORCID}

오세진(제1저자, https://orcid.org/0000-0002-8103-8216); 임동선(교신저자, https://orcid.org/0000-0001-8254-9504); 성지은(공동저자, https://orcid.org/0000-0002-1734-0058) 